\title{
AFETIVIDADE E CONHECIMENTO NA PRÁTICA PEDAGÓGICA DE SALA DE AULA ${ }^{1}$
}

\author{
Raimundo Nonato de Oliveira Falabelo ${ }^{2}$
}

Resumo: Alguns estudos revisados, sobre o tema da afetividade na sala de aula, apresentam uma visão de concordância ao focalizarem a afetividade como uma instância subjetiva muito mais centrada no professor, tendo este o poder de usá-la para modular a configuração das relaçôes pedagógicas e assim obter sucesso nos resultados do ensino e da aprendizagem. Buscando enfocar a afetividade de forma diferente a esses estudos, este trabalho tem como objetivo apresentar algumas conclusôes sobre o que denomino como a indissociável inter-relação afetividade-conhecimento-intelecto/cognição, com base no argumento de que todas se interpenetram e se afetam mutuamente nas práticas de ensino e de aprendizagem dos conhecimentos escolarizados. Como referencial, tomou alguns dos estudos de Vigotski sobre sua concepção histórico-cultural do desenvolvimento humano e ainda leva em consideração o fato dessa perspectiva teórico-metodológica privilegiar a análise da dinâmica interativa em suas condiçóes sociais de produção e, dentro destas, as formas de singularização do sujeito Os dados, apreendidos por meio de observaçóes e entrevistas, foram organizados em narrativas, tendo sido eleitos alunos/as e professores/as como personagens, no contexto sobre os quais foram realizados os comentários analíticos. Conclui que se faz necessário estar atento às formas como os sujeitos significam as suas vivências, experiências, e as relaçóes com o conhecimento no espaço escolar, pois a escola é o locus mais importante para o desenvolvimento intelectual/cognitivo, socioafetivo e emocional dos sujeitos.

Palavras-chave: Escola. Ensino. Aprendizagem. Afetos. Emoçóes.

1 Em agradecimento, dedico este artigo à Profa. Dra. Roseli A. C. Fontana (Unicamp/SP), minha orientadora no Doutorado, por suas relevantes orientaçóes e contribuiçôes à elaboração da compreensão sobre afetividade que desenvolvo neste artigo.

2 Doutor em Educação (UNIMEP/Piracicaba/SP), Especialista em Literatura, Leitura e Formação de Leitores (UFPA). Prof. da Faculdade de Educação e Ciências Sociais - Curso de Pedagogia - Campus Abaetetuba/UFPA. Prof. do Programa de Pós-Graduação em Educação e Cultura (PPGEDUC) - Campus Universitário de Cametá/UFPA. Coordenador do Grupo de Estudos e Pesquisa em Linguagem, Alfabetização, Emoções e Subjetividade (GEPLAES). E-mail: falabelo@ufpa.br ORCID: https://orcid.org/0000-0003-1193-8072 


\title{
AFFECTIVITY AND KNOWLEDGE IN CLASSROOM PEDAGOGICAL PRACTICE
}

\begin{abstract}
Some revised studies on the subject of affectivity in the classroom, show a view of agreement when focusing on affectivity as a subjective instance much more centered on the teacher, who has the power to use it to modulate the configuration of pedagogical relationships and thus succeed in teaching and learning outcomes. Seeking to focus affectivity differently to these studies, this paper aims to present some conclusions from my research on what I call the inseparable affectivity knowledge - intellect / cognition interrelation, with the argument that they interpenetrate and affect each other. mutually in the teaching and learning practices of schooled knowledge. As a reference, some of Vigotski's studies on his historical-cultural conception of human development are taken, and the fact that this theoretical-methodological perspective favors the analysis of interactive dynamics in his social conditions of production and, within these, the forms of individualization of the subject The data, apprehended through observations and interviews, were organized in narratives, electing students as teachers, in the context of which the analytical comments were made. It is concluded that it is necessary to be attentive to the ways in which the subjects signify their experiences and the relations with knowledge in the school space, as the school is the most important locus for intellectual / cognitive, socio-affective and emotional development of the subjects.
\end{abstract}

Keywords: School. Teaching. Learning. Affections. Emotions.

\section{Introduçáo}

A emoção não é uma ferramenta menos importante que o pensamento.

(Vigotski, 2003).

Este trabalho tem como objetivo apresentar algumas conclusões de estudos e pesquisas sobre o que se denomina como a indissociável inte-relação afetividadeconhecimento-intelecto/cogniçâa ${ }^{3}$, com o argumento de que se interpenetram e se afetam mutuamente nas práticas de ensino e de aprendizagem dos conhecimentos conteúdos escolarizados. Tem-se observado, com certa frequência, que, no cotidiano da escola, a afetividade - volta e meia - é referida como sendo um componente inerente a determinados sujeitos, aqueles que apresentam dificuldades nas tarefas e têm como resultado, repetências contínuas e abandonos recorrentes.

$\mathrm{Na}$ modalidade da educação de jovens e adultos (EJA), na qual se tem um longo envolvimento, como professor, pesquisador e orientador de Trabalhos de

3 Vigotski não usa o termo cognição/cognitivo, que tem sido mais relacionado, atualmente, no meio educacional, ao construtivismo piagetiano. O pesquisador utiliza termos, como mente, intelecto, função mental, funçóes psicológicas superiores. Emprega-se neste artigo a expressão intelecto/cognição para significar faculdade mental, mente, inteligência, percepção, memória, raciocínio, juízo; capacidade de entendimento, compreensão. 
Conclusão de Curso ${ }^{4}$, essa compreensão de afetividade aparece como uma espécie de senso comum, com status de "verdade" científica, a explicar fragilidades na aprendizagem. Muitos sujeitos que buscam a EJA são vistos como carentes afetivos, que possuem baixa autoestima, o que sempre leva à evasão escolar, táo comum e radical nessa modalidade. Igualmente, tem-se verificado que essa mesma "verdade" é usada para explicar as reprovaçôes nos anos iniciais do ensino fundamental, principalmente nas escolas localizadas em áreas periféricas. A percepção de que determinadas crianças náo aprendem porque são carentes de afetividade, acaba por se tornar uma explicação que se evidencia em verbalizaçóes e açóes didáticas.

No campo acadêmico, os estudos sobre a afetividade na sala de aula, resultante de um levantamento bibliográfico das poucas pesquisas já realizadas, que, direta ou indiretamente tratavam desse tema, podem ser reunidos - grosso modo - em quatro aspectos, os quais serão apresentados, a seguir, de forma breve ${ }^{5}$.

O primeiro aspecto mais relevante desses estudos é sua argumentação central de que a afetividade e cognição são dimensões dicotômicas e, por isso, a afetividade se mostra até mesmo como prejudicial ao processo pedagógico. Um segundo aspecto que emerge dos estudos revisados - voltados à pesquisa das práticas do bom professor - mesmo sem se tomar a afetividade/afeto como questáo central, chega à conclusão que a "boa prática pedagógica" é aquela cujos professores lançam mão dos recursos afetivos. Aqui a afetividade aparece com um "dom" que somente alguns professores possuem, e aqueles que o exploram, adequadamente, têm sucesso na sala de aula. Esses seriam, então, os "professores bem-sucedidos".

O terceiro aspecto evidencia-se mais preocupado em investigar as percepçóes dos professores sobre o papel dessa dimensão afetiva em suas práticas ou enfocar a questão do domínio das emoçôes/afetividade como forma de melhor garantir as condiçóes para a realizaçáo do ensino e da aprendizagem. O controle, racional, das emoçôes e da afetividade se constituiriam em poderosa ferramenta para o sucesso da prática docente e da aprendizagem.

Assim, centrada na figura do professor, teria a afetividade o poder de modular a configuração das relações pedagógicas. Emergem, dessa concepção, orientaçóes didáticas a postular a necessidade de o professor dominar a questáo afetiva/emocional como forma de desenvolver/organizar/controlar suas atividades pedagógicas, bem como a aprendizagem de seus/suas alunos/as. O sucesso do

4 Na graduação, tem-se orientado alguns Trabalhos de Conclusão de Curso (TCCs) com a temática da Afetividade e observado a dificuldade para que os/as orientandos/as avancem além da compreensão de afetividade como uma instância subjetiva identificada como sentimento de malogros constantes, baixa autoestima, baixa autoimagem. Na pós-graduação, em algumas dissertaçōes, vem-se produzindo uma discussão que busca desenvolver uma compreensão da afetividade como instância indissociável da relaçáo conhecimento-intelecto/cogniçâo na sala de aula.

5 Apresenta-se aqui um breve resumo do "estado da arte" (FALABELO, 2005). 
empreendimento docente dependeria de se saber controlar ou náo, a afetividade e a emoção em benefício do ensino e da aprendizagem.

Por último, um quarto grupo analisa a afetividade e sua relação com o intelecto/cognição. Nesse, busca-se evidências da interação entre os aspectos do desenvolvimento dos afetos e das emoçóes no contexto das relaçóes que ocorrem no cotidiano escolar, mais especificamente nas relaçóes professor/a-alunos/asconhecimentos escolares. Verifica-se todo um esforço teórico no sentido conceituar afetos e emoções no campo da significação.

Assim, diante da breve exposição, este artigo traz como objetivo precípuo aprofundar a discussão teórica sobre a indissociabilidade entre os aspectos afetivoemocionais e conhecimentos escolarizados, desenvolvendo um esforço de analisar esses conceitos no campo da significação, da história e da cultura. A relevância deste estudo está em apresentar argumentaçôes que avancem na compreensão da afetividade/emoçôes nas práticas de ensino e aprendizagem numa abordagem inter-relacional com o conhecimento/intelecto/cognição, enquanto indissociável totalidade que constituiria a vida psíquica humana. Assume-se como pressuposto de que a afetividade estaria presente e seria constitutiva de toda e qualquer ação humana. Procura-se evidenciar como afetividade/emoçóes e intelecto/cognição se inter-relacionam nas situaçóes de ensino e aprendizagem, no contexto das dinâmicas interativas em sala de aula, em suas condiçóes sociais e imediatas de produção. Como base nesse pressuposto, argumenta-se em defesa da indissociável interrelação entre afetividade-conhecimento-intelecto/cognição, considerando-se que se interpenetram e se afetam mutuamente no processo de ensino e aprendizagem.

Pode-se ainda destacar, além da contribuição teórica e acadêmica, que essa discussão se propóe, sua importância pedagógica, no sentido de colaborar para o aprofundamento e esclarecimento do lugar da dimensão afetiva e emocional nos processos de ensino e aprendizagem dos conhecimentos escolares.

\section{Práticas de Ensino e de Aprendizagem}

Assume-se, como referencial teórico, alguns dos estudos de Vigotski (2000a, 2000b, 1999, 1997, 2001, 2003, 2004) sobre sua concepção histórico-cultural do desenvolvimento humano; recorre-se, ainda, a autores que se referenciam as ideias vigotskianas para a fundamentação de suas pesquisas teóricas e empíricas. Ainda, lança-se mão de contribuiçôes de autores que se aproximam da abordagem teórica desse autor.

Considera-se importante destacar, ainda, que se tomou esse autor como referencial teórico, dada a perspectiva teórico-metodológica que privilegia a análise da dinâmica interativa em suas condições sociais de produção e, dentro destas, as formas de singularizaçáo do sujeito. Ou seja, é central em suas ideias, o pressuposto de que o indivíduo se constitui nas relaçóes sociais, sempre e necessariamente com o outro, mediados pelos significados culturais. 
O trabalho de campo foi realizado em duas classes de EJA, que funcionavam num distante bairro periférico, Colina dos Arvoredos, de uma cidade do interior de Sáo Paulo, Primavera do Sol't. Os dados, apreendidos por meio de observaçóes e entrevistas, foram organizados em narrativas, elegendo-se alunos/as e professores/ as como personagens, no contexto, acerca das quais se realizou os comentários analíticos.

Considerando-se que o objetivo deste trabalho é apresentar algumas argumentaçôes finais de tese de doutorado - com algumas modificações e adequaçóes ao formato de artigo acadêmico - sobre a temática da afetividade, náo serão apresentados dados empíricos. A ênfase, assim, está em trazer a síntese das discussões em seu desenvolvimento teórico sobre o tema. Acredita-se, ainda, que a relevância, em publicar este trabalho, está em sua contribuição para ampliar estudos sobre afetividade nas práticas de ensino e aprendizagem, dentro de uma perspectiva inter-relacional, como também, reveste-se de uma importante contribuiçáo para se pensar açóes nos ambientes didáticos e pedagógicos.

\section{Resultados e Discussóes}

\subsection{Vigotski e as Necessárias Pistas à Compreensáo da Unidade entre Afetividade e Cogniçáo/Conhecimento ${ }^{7}$}

A essência humana não é uma abstração inerente ao indivíduo considerado à parte. Em sua realidade, é o conjunto das relaçôes sociais. (MARX; ENGELS, 1979).

Para pensar o sujeito em suas condiçóes de vida material, cultural e existencial, bem como em suas relaçóes com as práticas do aprender, tomou-se como referência os trabalhos de Vigotski e colaboradores sobre o desenvolvimento histórico do indivíduo, nos quais se destacam a mediação ${ }^{8}$ simbólica ou semiótica e o papel do/a

6 O nome da cidade, do bairro, assim como dos/as professores/as, alunos/as foram substituídos por nomes fictícios.

7 A discussão, mais aprofundada, dessa temática, encontra-se no referencial teórico, da tese de doutorado (FALABELO, 2005).

8 Mediação é um dos conceitos centrais para a compreensão da abordagem vigotskiana. "Mediação, em termos genéricos, é o processo de intervenção de um elemento intermediário numa relação; a relação deixa, então, de ser direta e passa a ser mediada por esse elemento" (OLIVEIRA, 1997, p. 26). Vigotski destaca dois tipos de mediadores: os instrumentos e os signos. Genericamente, instrumentos são externos aos indivíduos e se referem a todo equipamento que permite, ao homem, estabelecer uma relação de trabalho-transformação da natureza, produzindo cultura. Os signos têm sua orientação para o interior dos indivíduos, por isso denominados por Vigotski de "instrumentos psicológicos" e têm como função o controle das funçôes psicológicas. A palavra, pare esse autor, é o signo mais importante. 
outro/a como constituidores/as das funçóes psíquicas. Essas referências à formação dos aspectos denominados de especificamente humanos, têm seus vínculos na concepção da história, expressa na tese de Marx sobre Fuerbach, que abre este tópico como epígrafe, em que Marx faz uma espécie de advertência ao estudo e compreensão dessa especificidade: o indivíduo, o sujeito, a subjetividade humana - seja qual for a palavra para designar o funcionamento psíquico humano - náo podem ser compreendidos sem se considerar o conjunto das relaçôes sociais nas quais o indivíduo está inserido.

Uma das questôes centrais, abordadas por Vigotski, é o desenvolvimento do intelecto/cognição, denominado de funçóes psicológicas superiores. Em alguns de seus escritos, é possível encontrar interessantes pistas para se pensar a questão do desenvolvimento emocional e afetivo para além de uma visão eminentemente biológica e ou dicotômica. As pistas acerca dessa importante dimensão referemse à complexa e dinâmica unidade existente entre intelecto/cognição e emoçóesafetividade-afetos.

A criança, objeto de seus estudos, constitui-se nas relaçóes intersubjetivas mediadas pelo conhecimento e pela cultura. Aquilo que se denomina de hominização dá-se na arena da história, pois, “[...] o desenvolvimento psicológico dos homens é parte do desenvolvimento histórico geral de nossa espécie e assim deve ser entendido" (VIGOTSKI, 2000b, p. 80). Fazendo-se na história, a explicação para a constituição dos sujeitos não pode ser buscada, unicamente, nos indivíduos, tomados de forma isolada, mas no amago as relaçóes sociais por eles vividas, das quais a linguagem (signos verbais e não verbais) é constitutiva. Vigotski (2001) valoriza a linguagem - a palavra - enquanto signo primordial ao desenvolvimento das funçóes psicológicas superiores e o considera como fundamental na organização e controle de nossos estados d'alma.

Dessa maneira, as funçôes psicológicas superiores (cognitivas/pensamento, atenção, linguagem, percepção, emoção, afetividade), como conteúdo da subjetividade, têm o seu desenvolvimento modulado, náo apenas por elementos orgânicos, de caráter inatos, mas sofrem os condicionantes dos processos mediadores da história e da cultura em que o sujeito tem sua pertença. As manifestaçôes afetivas, por exemplo, tanto têm vínculos com a emoção, entendida como impulsão dos aspectos neurofisiológicos, orgânicos, quanto são mediadas semioticamente. $\mathrm{Ou}$ seja, são nomeadas, reconhecidas, pois significam nas relaçóes e práticas sociais e têm sua expressão regulada (liberada ou constrangida) e modulada nas relaçôes sociais (FALABELO, 2005).

A afetividade e a emoção possuem uma especificidade histórico-cultural. A cultura e a história desempenham papéis fundamentais nas formas como os indivíduos vivem e expressam sua vida emocional e afetiva. As formas de perceber nossas emoções, de reagir a elas e de manifestá-las, bem como a nomeação, o reconhecimento e a manifestação de nossos sentimentos e nosso controle (intelectual, cognitivo) sobre eles são históricos e mediados pelos elementos semióticos da cultura. As formas como vivemos nossos vínculos afetivos e nossas emoçóes configuram- 
se também como práticas culturais próprias a uma determinada sociedade, a determinados momentos de sua história (FALABELO, 2005).

De modo que a vivência emocional e afetiva do indivíduo, em sociedade, não é a expressão única de impulsos orgânicos, mas manifestação de processos de "culturalização" do biológico, na indissociável inter-relação entre emoçôes, afetos e intelecto/cognição. Isto é, pode-se dizer que emoçôes e afetos também são modulados pela razão e pela educação. "A educação das emoçôes sempre é, uma reeducação das emoções, isto é, uma modificação na direção da reação emocional inata" (VIGOTSKI, 2003, p. 120). Essa educação dá-se por meio da apropriaçáo da linguagem/palavra e das significações sociais. O que Vigotski denomina de reeducação das emoçóes ocorre no campo da aprendizagem, seja formal ou informal, sistemática ou cotidiana.

No estudo das funçôes psicológicas superiores, a palavra, para Vigotski (2000a, 2000b, 2001), tem um papel indispensável na constituição da percepção, organização, reestruturação e no controle da atividade psíquica, em que se incluem os estados emocionais e afetivos. Precisa-se de signos para perceber o mundo, para nele nos situarmos, observá-lo e apreciá-lo, para nos compreendermos nele e os nossos "estados de alma". A palavra, por conseguinte, é o signo por excelência na constituição da estrutura psíquica.

O signo nos permite superar o imediatismo das relaçóes com o ambiente e com nossos outros, podendo controlar nossa atenção, modular nossos sentimentos, reorganizar nossa percepção, redimensionar os significados e sentidos com que nos elaboramos, ao longo de nossa história pessoal, que é, sempre e necessariamente, social.

Diferentemente dos animais, em quem a emoçáo é de ordem estritamente orgânica, nossos estados emocionais e sua expressáo são modulados em seu funcionamento por signos, dos quais nos apropriamos nas relaçóes sociais vividas. Internalizados, ou seja, reconstruídos internamente, esses signos nos constituem e configuram nossa singularidade, em termos intelectuais/cognitivos, emocionaisafetivos e valorativos. Como indivíduos náo nos aproximamos dos objetos de conhecimento, apenas como um ser de intelecto/cogniçáo, mas como um ser em sua totalidade, feito de afetos/sentimentos, racionalidade, emoção e valores.

Como escreve Vigotski (2004, p. 185), “[...] a palavra, ao crescer na consciência, modifica todas as relaçóes e todos os processos; o próprio significado da palavra evolui em função da mudança da consciência”. O acesso à palavra - às significaçôes - é a condição fundamental para o desenvolvimento da consciência, em conformidade com essa citação. A palavra, ao crescer na consciência, promove a capacidade de o sujeito usar as significações nas diversas situaçôes de vida social, cognitiva, intelectual, afetiva e emocional. As significaçôes constrangem e expandem os usos dos comportamentos considerados tipicamente humanos. Vigotski, ao dizer que a palavra "cresce" na consciência, estaria pressupondo que os fundamentos da formação da consciência devem ser vistos no campo da educação e da aprendizagem: é aprendendo as significaçôes/conhecimentos/valores/sentimentos de seu grupo 
social, nas relaçóes sociais formais e espontâneas, que a criança vai constituindo sua consciência e apropriando-se dos modos sociais/culturais de comportar-se e agir.

Ao supor que as funçôes psicológicas superiores têm seu desenvolvimento no terreno da história e da cultura, está Vigotski sugerindo que a capacidade mental - de dar significado e sentido às coisas, a capacidade de ordenar e organizar em categorias os objetos e os seres do mundo, de forma inteligível no plano individual e social - é uma estrutura que depende dos processos de aprendizagem. A criança encontra-se diante da necessidade aprender as categorias, com as quais vai se relacionar com o mundo. Por exemplo, a criança inicia - com a ajuda parental ou outro adulto próximo - a ordenar os objetos e seres ao seu redor em categorias, com forte laço emocional e afetivo, como objetos "pegar", "apertar", "sugar"; categorias parentais, como "pai", "mãe", "irmão", "irmâ", etc.

Vigotski (2000a, 2000b, 2004) faz severa crítica à psicologia tradicional que vê a consciência humana como um objeto clivado, de um lado as funçóes cognitivas e de outro, as afetivas. Segundo o estudioso, a separação do lado intelectual de nossa consciência de seu lado afetivo-volitivo transforma o pensamento em um fluxo autônomo de pensamentos que se pensam a si mesmos, separados de toda plenitude da vida real, dos motivos de viver, dos interesses e das atrações do ser humano inteligente.

É o indivíduo, como uma unidade, inserida na totalidade social, que, mediado pela linguagem (palavra/signos), elabora significados e sentidos, atribui-lhes ou não validade, julga-os, conhece e aprende. Suas necessidades, motivaçóes, interesses e desejos são constitutivos desses significados e sentidos, uma vez que por trás de cada pensamento, afirma Vigotski (2000b), há uma tendência afetivo-volitiva e uma compreensão plena do pensamento de outrem só é possível quando se entende essa base afetivo-volitiva. Destaque-se que nesta citação, o autor chama a atenção para o fato de que o pensamento e comportamento humanos não resultam, unicamente, de um ato intelectual, racional, mas que são indissociáveis das dimensões afetivas e volitivas. A esse respeito, significaria dizer que, ao se analisar comportamento e ação humanos, que decorrem com uma complexidade de fatores, não se poderia excluir, dessa compreensão, os fatores da emoção-afetos e os volitivos.

Portanto, diz Vigotski (2000b, 2001) que a separação do pensamento das outras manifestaçóes da atividade mental dos sujeitos, resulta em um tipo de pensamento sem significado, incapaz de modificar qualquer coisa na vida ou na conduta de uma pessoa, como uma espécie de força primeva a exercer influência sobre a vida pessoal, de um modo misterioso e inexplicável.

A inter-relação entre afetivo e intelectual, indicia-se no signo, na palavra. É na palavra que o afetivo e o intelectual se unem, à medida que a palavra contém uma atitude afetiva transmutada com relação ao fragmento de realidade ao qual se refere. Nesse sentido, ela nos permite seguir a trajetória que vai das necessidades e impulsos de uma pessoa até a direçáo específica tomada por seus pensamentos, e o caminho inverso, a partir de seus pensamentos até o seu comportamento e a sua atividade (VIGOTSKI 2000b, 2001). 
A palavra, entáo, que é pronunciada pelos sujeitos, traz as marcas de suas vivências afetivas e volitivas, de sua historicidade e singularidade e, nesse sentido, realiza a unidade entre o afetivo e o intelecto/cognitivo. $\mathrm{O}$ significado é alterado pelo contexto vivencial e afetivo dos sujeitos em suas relaçóes sociais. Logo, é na palavra, explorando sua significaçáo, que Vigotski vai pensar a indissociabilidade e a unidade do funcionamento psicológico do indivíduo, entre a dimensão intelectual/ cognitiva e a afetivo-emocional.

\subsection{A Indissociabilidade Afetividade-Intelecto/Cogniçáo/Conhecimento}

Neste tópico, apresenta-se algumas argumentaçóes do estudo sobre a indissociável inter-relação entre afetividade e intelecto/cognição/conhecimento", com base em algumas pistas apresentadas por Vigotski quando este enfoca o desenvolvimento humano e a constituição das funçóes psicológicas superiores.

Inicia-se argumentado que o disparador à aprendizagem dos indivíduos (professor/a e aluno/a), para o seu movimento em direção à apropriação dos conhecimentos - e que se reverte em mudanças em suas práticas e modos de viver as relaçóes pedagógicas - não decorre apenas de um investimento meramente intelectual, mas que esse movimento passa, necessariamente, pelos componentes emocionais e afetivos. Em outras palavras, o movimento à alteraçáo de suas atitudes anteriores, dá-se articulado aos afetos e intelecto/cognição, na medida em que o sujeito se sente afetado em sua subjetividade pelos significados e sentidos apropriados nas relaçóes intersubjetivas, tendo o conhecimento como base.

Essa argumentação apoia-se em Vigotski (1997, p. 266) quando o autor chama a atenção para o fato de que as açóes dos sujeitos "[...] não nascem sem causa, mas que são movidas por determinados processos dinâmicos, necessidades e estímulos afetivos". Ainda para o autor, "[...] o pensamento sempre é motivado, está sempre psicologicamente condicionado, deriva sempre de algum estímulo afetivo, através do qual é colocado em movimento e orientado". Depreende-se, desse modo, que intelecto/cognição e o pensamento, como uma atividade do intelecto/cogniçáo, move-se sob estímulos afetivos, daí a afirmação de Vigotski de que a separação entre pensamento e afetividade resulta em pensamento sem sentido para o sujeito, desprovido de capacidades mobilizadoras que o levem a agir.

A partir dessas pistas, pode-se dizer que o interesse à aprendizagem nasce de necessidades e dos estímulos afetivos do sujeito em suas relaçôes com os conhecimentos escolares. Náo se trata, portanto, de apropriaçáo de meras informaçôes, mas de conhecimentos e experiências que se ligam e dáo sentido à vida em sua totalidade, que envolve os componentes intelectual e afetivo e não somente

9 Conforme já se ressaltou na Introdução, essa discussão apresenta modificaçóes e adequaçóes ao texto original de Tese de Doutorado, dadas as leituras e reflexóes que se vêm realizando atualmente sobre o tema no Grupo de Estudos e Pesquisa em Linguagem, Alfabetização, Emoçôes e Subjetividade (GEPLAES). 
à especificidade de uma determinada atividade - em seu aspecto pragmático e utilitário.

O conhecimento é assumido como constitutivo da subjetividade e não apenas com parte de uma obrigaçáo operacional que professores/as e alunos/ as devam cumprir: ensinar e aprender alimentam-se no jogo da inter-relação entre conhecimento/ intelecto/cognição e afetos, entre conhecimento e vida. O conhecimento, em sua significação, possui uma dimensão afetiva, que se conecta ao intelecto/cognição. Aprender pressupóe a promoção do desenvolvimento intelectual/cognitivo por meio do conhecimento - apropriado em suas significaçóes e seus sentidos. Aprender, também, pressupóe apropriar-se do que é significativo para o sujeito e aquilo que é significativo para o sujeito pressupóe um investimento emocional e afetivo. $\mathrm{O}$ afetivo indicia-se na significação e vice-versa.

As relações intersubjetivas, mediadas pelo conhecimento, estão entrelaçadas pelos afetos, pois os sentidos e significados que emergem nessas relaçôes de conhecimento - ao se expressarem em afetos de alegria e prazer, que são compartilhados pelos sujeitos da relação de ensino e de aprendizagem (professores/as e alunos/as), mobilizam-nos em direção a novos movimentos de ensinar e aprender, formar-se e transformar-se. Diferentemente, em sua ambivalência, esses sentidos e significados podem motivar, também, a expressão de afetos de desinteresse, desprazer, fuga das atividades. Em relação a essas experiências, vividas por alunos/ as e professoras/es, poderia supor-se que a formação/aprender, que ocorrem nas relaçôes intersubjetivas, mediadas por conhecimentos significativos, delas náo estão ausentes os aspectos afetivos, enquanto impulso que coloca o pensamento em movimento e em direção à ação.

A apropriação dos conhecimentos é mediada pelos aspectos afetivos, porque dependente da apreciação que se faz dos signos e sentidos em circulação. Não se apreende e aprende apenas conteúdos objetivos, mas sentidos e significados, de modo que essa apreciação náo se reduz a uma operação unicamente intelectual, mas faz-se fundada em valores, afetos, ideologia, experiência e nas condiçóes sociais e hierárquicas do indivíduo no contexto de suas relaçôes sociais e culturais.

Em relação à essa discussão, Charlot (2000) apresenta compreensões compatíveis com a abordagem histórico-cultural, ao argumentar que o social é apropriado pelo sujeito de uma forma específica, a partir de seus interesses, das normas e dos papéis que a ele são postos ou impostos. Esse sujeito, como um ser singular, apropria-se do social em forma de representaçóes, comportamentos, aspiraçôes, práticas, etc. Ou seja, o que é apropriado pelo sujeito nas relações intersubjetivas, não são objetos e/ou relações materiais, mas representaçóes, que se constituem no conteúdo psíquico do sujeito. Daí a assertiva de Vigotski em pressupor o papel fundamental da apropriação da cultura/conhecimentos para a promoção do desenvolvimento das funçôes psicológicas superiores.

Para Vigotski (2000b, 2001), é a internalização dos conhecimentos que promove o desenvolvimento do sujeito. A afetividade, então, mostra-se nas relações de aprendizagem quando o sujeito tem acesso a experiências significativas. Assim, 
por exemplo, os afetos de prazer, alegria, de gostar, de náo gostar, de indiferença, etc., decorrem da relação apreciativa que o sujeito estabelece com o conhecimento, a partir dos significados e sentidos que atribui a esse objeto, nas suas demandas para conhecer, saber, desenvolver-se intelectual, social, emocional e afetivamente. Desse modo, segundo Oliveira (2001, p. 52), estudiosa de Vigotski, podemos compreender os afetos e "[...] as emoçóes enquanto modos de sentir culturalmente circunscritos e socialmente construídos", na dinâmica das interaçôes sociais e em determinadas condiçōes concretas de produção do ensino e da aprendizagem.

Vigotski (2003) considera que as emoções são uma espécie de resultado da avaliaçáo que o próprio sujeito faz de sua relação com o ambiente sociocultural. A partir dessa colocação, pode-se supor que as emoçóes moduladas em afetos de alegria, prazer, entusiasmo, bem como de insegurança, medo, raiva, recusa manifestadas por alunos/as na dinâmica interativa da sala de aula, decorrem da apreciaçáo dos sentidos e significados que passam a atribuir à relaçáo pedagógica, à apropriaçáo dos conhecimentos disponibilizados e aos avanços no desenvolvimento intelectual, cognitivo. Por sua vez, são essas emoçôes e afetos - significados nas relaçôes concretas de produçáo - que mobilizam, por um lado, os/as alunos/as a avançar ou não em suas aprendizagens e, por outro lado, no caso de professores/ as, a diversificar seu trabalho, a criar alternativas, a desenvolver-se em sua formação profissional.

Nesse sentido, as emoçôes e afetos, que se originam no processo de compreensão-aprendizagem dos conhecimentos, ao mesmo tempo, alimentam e expandem esse processo, em sua relação dialética, de forma que afeto e intelecto/ cognição vão se transformando mutuamente. $\mathrm{O}$ ato de conhecer produz mudanças na condição afetiva de alunos/as e de professores/as que, por sua vez, os mobilizam a aprender/conhecer mais. Ou seja, conforme Vigotski (1997), em sua relação dialética, causa e efeito mudam de lugar, com a causa tornando-se efeito e vice-versa. Um fenômeno psíquico, ao surgir, exerce influência nos processos que lhe deram origem, motivando a emergência de novos fenômenos, consolidando e expandindo as funções psicológicas.

Portanto, se a compreensão (o ato de aprender, conhecer) produz a emergência de emoçôes e afetos de prazer, por sua vez, essas emoçóes provocam alteraçôes nos processos intelectuais/cognitivos. A esse respeito, Vigotski (1997) diz que os objetos não mudam porque pensamos neles, mas o afeto e as funçóes inerentes a eles mudam em razão do fato de que são conscientes. São colocados em outra relação com a consciência e, por conseguinte, mudam sua relaçấo com o todo e com a unidade. Dessa forma, "[...] podemos dizer que para qualquer fase no desenvolvimento do pensamento corresponde, igualmente, uma fase no desenvolvimento dos afetos" (VIGOTSKI, 1997, p. 268), e das emoçóes, pode-se acrescentar. Temos aqui uma importante sinalização para a compreensão da indissociável inter-relação entre intelecto/cognição e afeto, pois o desenvolvimento do pensamento/intelecto/ cognição promove também o desenvolvimento das emoçóes e dos afetos e viceversa. 
Essas reflexôes levam a supor que é a compreensão (entendimento, o ato de aprender e apreender algo, um conceito, por exemplo) que suscita o afeto de prazer e alegria e se constitui no detonador da mobilização do sujeito. Referindo-se a experiências docentes, que são vividas por professores/as e alunos/as, nas suas relações com os conhecimentos escolares, pode-se inferir que esses indivíduos produzem sentidos e significados que afetaram suas formas de trabalho (ensinar e aprender), levando-os/as a reorganizar e ressignificar seus comportamentos e atitudes, seja como atos de aprendizagens ou ação docente. Desse modo, nas relações intersubjetivas, mediadas pelos conhecimentos e pelo/a outro/a, reconfiguraram-se - nos sujeitos papéis, atitudes, comportamento e afetos; transformam-se e alteraram-se sentidos e significados; alteram-se, ampliam-se e enriquecem-se os "[...] estados emocionais e as formas de sentir e agir" (OLIVEIRA, 2000, p. 46) em relação a si mesmo/a, aos/ as outros/as e à própria atividade de ensino e de aprendizagem.

Altera-se, portanto, toda a unidade da vida psíquica do sujeito e não meramente uma dimensão racional, instrumental ou pragmática, isso porque o processo de conhecimento, não é "[...] obra unicamente da razão, nem como simples efeito da experiência sensível nem ainda como resultado da interação direta entre sujeito e objeto.", afirma Pino ([2001?], p. 18), estudioso da obra de Vigotski, mas é o resultado da experiência de um sujeito "[...] provido de qualidades afetivocognitivas e que está 'sob a primazia da subjetividade." (CHARLOT, 2000, p. 61).

Ao longo de sua formaçáo como ser humano, na arena das relaçôes sociais e simbólicas, o sujeito vai construindo e reconstruindo, numa dialética ininterrupta, formas, modelos, indicadores de como agir e de como sentir, que orientam as suas relaçôes com os outros e com os objetos culturais (OLIVEIRA, 2000). Os sujeitos precisam de representaçôes, símbolos, imagens, valores, sentimentos e crenças para viver e compor sua própria subjetividade, relacionar-se e desenvolver suas atividades sociais. Mas esses componentes não são fixos e imutáveis, pois se transformam nas dinâmicas interativas, o que significa dizer que os sujeitos estão sempre sendo afetados em suas subjetividades por valores, significados e sentidos compartilhados e vividos social e culturalmente. Vigotski considera a educação como um dos locus, por excelência, para esse processo de desenvolvimento.

Nesse sentido, o movimento de alteração e ressignificação dos sentidos (de nossas concepções e percepçôes), isto é, o movimento deliberado em direção a nossa formação - de constituição da unidade da vida psíquica -, vai depender da qualidade e da natureza das experiências que vivemos e de sua capacidade em afetar a nossa subjetividade. Parece que é nesse sentido que Vigotski (2000b) diz que nem toda relaçáo com o conhecimento promove o desenvolvimento, ou seja, nem toda relaçáo com o conhecimento se constitui em relaçáo de aprendizagem, isto é, em mudanças, transformaçôes nas funções psicológicas superiores do sujeito. Por conseguinte, pode-se supor que o processo de desenvolvimento é desencadeado por tudo aquilo que repercute "na natureza sensível do ser humano" (PINO, [2001?], p. 130), alterando essa natureza. Essa mudança é processo; é relação que o sujeito estabelece com os/as outros/as, mediado pelo simbólico e pela linguagem, e que resulta em aprendizagens daquilo que definem a espécie humana. Nessas relaçôes, 
intersubjetivas, não se aprende apenas de competências intelectuais, mas também dos modos afetivos, que se configuram em maneiras de se amar, de fruir prazer, de sentir alegria; de expressar sentimentos de ódio, de tristeza, de raiva, etc. Inferese, portanto, que é por meio das açóes dos/as outros/as, "de suas expressóes, de suas palavras" (OLIVEIRA, 2000, p. 50) que nos apropriamos do mundo e agimos sobre ele.

É nesse processo formativo que se vai imprimindo a esse fazer as marcas de nossa singularidade. Alteramos os significados, ampliamos e multiplicamos os sentidos em circulação. A observaçáo de Oliveira é pertinente, aqui, ao dizer que a passagem do nível interpsicológico para o intrapsicológico - que é na perspectiva vigotskiana, o processo de constituiçáo e desenvolvimento de nossa vida psíquica "[...] envolve, assim, relaçóes interpessoais densas, mediadas simbolicamente, e não trocas mecânicas limitadas a um patamar meramente intelectual” (OLIVEIRA, 1992, p. 80). Pode-se inferir que densas relaçóes intersubjetivas, experimentadas na riqueza dos investimentos no campo do simbólico e da diversidade de alternativas didáticopedagógicas, vividas na sala de aula, fariam emergir manifestaçóes emocionais e afetivas de segurança, confiança, prazer, alegria, autoestima revigorada, desejo de investir em novas aprendizagens, comprometimento, solidariedade, entusiasmo, etc., que se mostraram indissociáveis do aspecto intelectual/cognitivo. Professores/ as e alunos/as, igualmente, experimentariam relaçóes com o conhecimento no qual, o afetivo se configuraria como mobilizador e força psíquica para movimentá-los em direção ao desenvolvimento, isto é, aos investimentos nas atividades de ensino e de aprendizagem. Nesse sentido, inter-relação entre aspectos afetivos e intelecto/ cognição modulariam e transformariam atitudes e açôes, alterando e ampliando desejos e necessidades de aprender.

Contrariamente, considerando-se as reflexóes apresentadas até este momento, infere-se que experiências intersubjetivas, didáticas e pedagógicas, vivenciadas por alunos/as, também podem motivar expressão de determinadas manifestaçôes emocionais e afetivas de insegurança, de medo, recusa às atividades de aprendizagem, raiva, indiferença, solidão, ansiedade, etc., que seriam decorrentes de fatores diversos, entre os quais, possíveis inadequaçôes nas relaçôes de apropriação dos conhecimentos a que estariam sendo submetidos/as. Desse modo, longe de promover o movimento em direção ao desenvolvimento de suas funçóes mentais, nesse caso, as relaçóes intersubjetivas vividas em sala de aula produziram algumas formas de expressôes emocionais e afetivas, aqui nomeadas.

O afetivo, por conseguinte, nas relaçôes de ensino, não se caracterizaria apenas por uma única função, mas em sua ambivalência ou plurivalência, porque dependente da apreciação que o sujeito faz da relação com o meio sociocultural, dos sentidos e significados em circulação. As emoções e os afetos manifestar-seiam na dinâmica interativa em circunstância dos sentidos e significados que os sujeitos atribuem às suas relaçóes com o/a outro/a e com os objetos culturais - os conhecimentos escolarizados. 
É, portanto, o sujeito, em sua singularidade, que atribui sentidos às suas ações, atitudes e comportamentos e, essa atribuição, é dependente da leitura que faz de suas relaçóes, de modo que, pode-se dizer que esse sujeito faz apreciações diferentes sobre determinadas vivências e experiências, porque indissociáveis de seus valores, sentimentos, ideologias e crenças - base de tais apreciaçōes (VIGOTSKI, 2003).

Essas questóes evidenciam a necessidade de se pensar a afetividade na sala de aula não apenas como uma relaçáo mecânica de causa e efeito ou orientada por uma visáo maniqueísta que isole, de forma fixa e estática, afetos e emoçóes em negativos, de um lado, e em positivos, de outro. Mas, que ambos precisam ser pensados em sua plurivalência, em seu processo dialético e em seus imbricamentos com os aspectos intelectuais/cognitivos, sempre e necessariamente, na dinâmica das relaçóes intersubjetivas mediadas pelo conhecimento, e em determinadas condiçóes sociais de produção de se ensinar e de se aprender.

Em outras palavras, longe da visão de afetos/emoções negativos ou positivos, deve-se compreendê-los como dependentes da apreciação que o sujeito faz de sua relação com os objetos simbólicos e com os/as outros/as em determinado momento histórico, singular e irrepetível de sua vida. As emoçôes/afetos mostrar-se-iam como decorrentes dos efeitos produzidos pelos sentidos e significados em circulaçáo e que afetam a natureza sensível do sujeito - sua subjetividade.

Ainda, seria importante compreender que emoçôes/afetos são dimensôes inerentes à subjetividade, tanto de professores/as, como de alunos/as, bem como são característicos do próprio conhecimento e que são sempre relacionais, porque implicam relação de sentido e significação e, portando, são constitutivos da vida psíquica de todo indivíduo e, igualmente, dos objetos culturais e simbólicos como produtos da atividade humana.

Poder-se-ia, igualmente, falar, em afetividade do conhecimento, que é a significação e o sentido que os constituem - e que é justamente isso que nos afeta na relação sempre mediada com o/a outro/a em situaçáo de sala de aula. Vigotski (2000a), referindo à palavra, diz ela é um microcosmo da consciência, isso porque a palavra só pode ser compreendida como unidade de significação e sentidos. Seria possível, ainda, falar em afetividade da palavra, referindo-se à sua significação e aos sentidos que encerra e que nos afetam, mobilizam-nos, movem-nos, trespassamnos.

Desse modo, baseando-se nas considerações apresentadas, ressalta-se que afetividade/emoçóes estão presentes em toda e qualquer ação humana, a qual tem que ser examinada em sua constituição no plano do desenvolvimento histórico e cultural e em condiçóes sociais imediatas e concretas de produção, de forma que os afetos/emoçôes também não podem ser compreendidos fora dessa perspectiva. 


\section{Conclusóes}

Considera-se necessário estar atento às formas como são significadas as vivências, as experiências e as relaçóes com o conhecimento no espaço escolar, pois a escola - nas sociedades contemporâneas - se caracteriza como um dos loci mais importantes para o desenvolvimento intelectual/cognitivo, socioafetivo e emocional dos sujeitos. No cotidiano da sala de aula, então, deve-se observar os sentidos que são produzidos nas dinâmicas intersubjetivas, considerando-se que as manifestações afetivas são formas sígnicas, que expressam determinados modos de relação com as atividades de ensino e de aprendizagem e com professores/as, que se expressam em: gestos corporais, expressóes faciais, linguagem não verbal, tonalidade emocional da enunciação oral, marcas emocionais da escrita, etc.

Com base no referencial teórico, nega-se a dicotomia afetividade/emoçóes/ afetos e intelecto/cogniçấo, ressaltando-se a inadequação de se considerar essas duas dimensôes da vida psíquica de forma isolada; chama-se a atenção para o fato de que essas dimensóes se inter-relacionam e se afetam mutuamente, e somente nesse processo de indissociabilidade podem ser compreendidas. A afetividade/afetos é sempre relacional porque implica a relação de sentido e significação e, portanto, é constitutivo da vida psíquica de todo sujeito.

O afetivo, por conseguinte, nas relaçóes de ensino, náo se caracteriza apenas por uma única função (afeto positivo), mas em sua ambivalência ou plurivalência, porque dependente da apreciação que o sujeito faz da relação com o contexto sociocultural e histórico em que está inserido e dos sentidos e significados em circulação. Afetividade, emoçóes e os afetos, assim, manifestar-se-iam na dinâmica interativa em circunstância dos sentidos e significados que os sujeitos atribuem às suas relaçóes com o/a outro/a e com os objetos culturais, mediados pela linguagem.

\section{Referências}

CHARLOT, B. Da relaçáo com o saber: elementos para uma Teoria. Porto Alegre: ArtMed, 2000.

FALABELO, R. N. de O. A indissociável inter-relaçáo afetividade e cogniçáo nos processos de leitura e escrita na Educaçáo de Jovens e Adultos. 2005. 203 f. Tese (Doutorado em Educação) - Programa de Pós-Graduação em Educação, Universidade Metodista de Piracicaba, Piracicaba, 2005.

MARX, K.; ENGELS, F. A ideologia alemã. São Paulo: Livraria Editora Ciências Humanas, 1979.

OLIVEIRA, I. M. de. O sujeito que se emociona: signos e sentidos nas práticas culturais. 2001. 206 f. Tese (Doutorado em Educação) - Programa de Pós-Graduação em Educação, Universidade Estadual de Campinas, Campinas, 2001.

OLIVEIRA, M. K. de. O pensamento de Vygotsky como fonte de reflexão sobre educação. Cadernos CEDES, Campinas, n. 35, 2. ed., p. 11-18, jul. 2000. 
OLIVEIRA, M. K. de. O problema da afetividade em Vygotsky. In: LA TAILLE, Y. de. OLIVEIRA, M. K. de; DANTAS, H. Piaget, Vygotsky, Wallon: teorias psicogenéticas em discussão. São Paulo: Summus Editorial, 1992. p. 75-84.

PINO, A. Afetividade e vida de relação. Campinas: Faculdade de Educação/Unicamp, [2001?]. Mimeo.

VIGOTSKI, L. S. A construção do pensamento e da linguagem. São Paulo: Martins Fontes, 2001.

VIGOTSKI, L. S. A Educação do comportamento emocional. In: VIGOTSKI, L. S. Psicologia Pedagógica: edição comentada. Porto Alegre: Artmed, 2003. p. 113-114.

VIGOTSKI, L. S. A formação social da mente: o desenvolvimento dos processos psicológicos superiores. São Paulo: Martins Fontes, 2000 b.

VIGOTSKI, L. S. As emoções e seu desenvolvimento na infância. In: VIGOTSKI, L. S. O desenvolvimento psicológico na infância. Tradução de Claudia Berliner. São Paulo: Martins Fontes, 1999. p. 79-106.

VIGOTSKI, L. S. Fundamentos de defectologia. In: VIGOTSKI, L. S. Obras completas. Tradução de Maria del Carmen Ponce Fernandez. Havana: Editorial Pueblo y Educación, 1997. Tomo V, p. 74-87.

VIGOTSKI, L. S. Pensamento e linguagem. São Paulo: Martins Fontes, 2000a.

VIGOTSKI, L. S. Teoria e Método em Psicologia. São Paulo: Martins Fontes, 2004. 